\title{
Study of Relativity Theory of Einstein: The Story of Ashabul Kahf and Isra' Mi'raj
}

\author{
${ }^{*}$ F M Celina ${ }^{1}$, N Suprapto ${ }^{1}$ \\ ${ }^{1}$ Department of Physics, Faculty of Mathematics and Natural Science, Universitas Negeri Surabaya, Surabaya 60231, \\ Indonesia
}

\begin{tabular}{|c|c|}
\hline Article Info & ABSTRACT \\
\hline Article history: & \multirow{9}{*}{$\begin{array}{l}\text { Al Qur'an is the greatest miracle that used as a guide for Muslims in } \\
\text { the world. In it contains several verses that are relevant to physics. } \\
\text { The study aims to examine Einstein's Theory of Relativity in the } \\
\text { story of Ashabul Kahf and Isra' Mi'raj of Prophet Muhammad SAW. } \\
\text { A qualitative approach is used with the library research method by } \\
\text { analyzing related books and journals. The result show that the } \\
\text { relativity time of angles and humans can be explained by Einstein's } \\
\text { Theory of Relativity. Einstein's Theory of Relativity has nothing to } \\
\text { do with the Ashabul Kahf event. However, for the events of Isra' } \\
\text { Mi'raj of prophet Muhammad SAW, Einstein's Theory of Relativity } \\
\text { is not sufficient to prove it. }\end{array}$} \\
\hline Received November 11, 2020 & \\
\hline & \\
\hline Accepted December 8, 2020 & \\
\hline Available Online December 9, 2020 & \\
\hline Keywords: & \\
\hline Relativity & \\
\hline & \\
\hline & \\
\hline
\end{tabular}

\section{INTRODUCTION}

Al Qur'an is the greatest miracle of all times which is used as a guide for life for Muslims. The verses contained in it cover all aspects of education. Al Qur'an invites someone to think scientifically about the natural phenomena contained in it. It is not surprising that many of them want to study more deeply one of the phenomena that they find interesting. Researchers who have succeeded in proving the truth of the Qur'an, they do not hesitate to embrace Islam. Meanwhile for the common people, studying, examining and deepening the meaning of the verses of the Qur'an is a form of worship that can increase our devotion to Allah SWT (Lailiyah, 2020).

Physics is one of the pillars of science that is expected to have an impact on the times. Physicists have a very big influence on human life, because their research has succeeded in producing a theory. A theory will be able to change, if the theory is broken by a new theory. Al Qur' an and physics are one of the combined sciences that are often in the spotlight for students. The presence of the Ilmi Interpretation of the Ministry of Religion of the Republic of Indonesia is one of the government's efforts to break down the barrier between religion and science. The discourse of $\mathrm{Al}$ Qur'an integration continues to progress along with the shifting paradigm in seeing religion and science. Instead of saying that something related to the Qur'an is very interesting to study of research. It needs to be understood, that basically all the knowledge that is in life has been stated in the Qur'an, both implied and explicit (Faizin, 2020).

In the 20 2 th century, the world of modern science has been amazed by Einstein's Theory of Relativity. Theories relating to the delay of time. Time is not something absolute, the time interval that occurs from two different frames of reference causes time itself to be relative. Before Einstein, classical physics had always assumed that time was absolute. It turns out that the time itself has been explained in the Qur'an, one of which is in Surah Al Ma'arij verse 4: "The angles and Jibril rose (to face) to God, in a day the equivalent of fifty thousand years." The verse is always linked to Einstein's Theory of Relativity, this verse is often associated with 
Einstein's theory of relativity. One of the studies conducted by (Ain, Nurul, \& Ashari, 2018) states that scientific theory has not been able to accurately explain the phenomenon of Isra' Mi'raj. What is possible only through a theoretical approach regarding super fluidal and wormhole materials.

To prove its truth. As a student, it is appropriate as a student to do an in-depth study in order to practice the knowledge they have, this time the writer intends to study Einstein's concept of relativity of time which is relevant with the verses of the Qur'an. However, this research leads to the events of Ashabul Kahf and also Isra' Mi'raj of Prophet Muhammad SAW. Previously there have been several similar studies, it's just that it is still very minimal. Therefore, the authors have also analyzed the previous result.

Research has been conducted by (Rahmati, 2017) regarding the journey of Isra' and Mi'raj In Qur'an and Science Perspective discussed through the approach of The Zero Kelvin, The Collaboration of Einstein and Nath Bose. Isra' Mi'raj research was also carried out by (Istiqimah \& Sholeh, 2020) with understanding the concept of Buraq at the event. The results of the study are explained in two versions. From a literary perspective, Buraq is visualized as a riding animal with four legs which has a very high speed. Perspective serves an audience from the non-academic community. Meanwhile, according to the viewpoint of physicists, Buraq is correct as light that has a very high speed. This perspective is intended for audiences from the academic community.

The formulation of the problem in this research is whether Einstein's Theory of Relativity is related to the Ashabul Kahf event and the Isra' Mi'raj incident of Prophet Muhammad SAW, who so far are still confused about the truth. Because the word "time" has been spoken in the Qur'an with different meanings. Where, time can be fast or slow depending on the observer. Another purpose of studying Einstein's Theory of Relativity of time is to study the relevance between the two in order to increase scientific knowledge, as well as increase human confidence in the greatness of the miracles of the Qur'an that Allah SWT sent down through the angle Jibril. Specifically, this research uses the theory of the integration of religion and science (Wardah, 2018).

\section{RESEARCH METHOD}

This research used a qualitative research. Qualitative research is also called naturalistic research because it emphasizes the naturalness of data sources. The results of qualitative research are descriptive data in the form of written or spoken words from people and observed behavior (Margono, 2009). This research can also be said to be revelatory research. Revelatory research is one of the literary studies carried out on Al Qur'an texts concerning certain problems, for example education, economics, politics, and others, then the answers given by the Al Qur'an to these problems (Harahap, 2014).

This research uses library research type, also called literature research where data is obtained from the library without going into the field. The research method used is by studying the literature and writings that are closely relevant to the issues raised. Sources of data in library research use primary and secondary data sources. Primary data sources obtained directly from the first hand of the character, if the character is still alive or data obtained from writings that have been written by the character (Harahap, 2014). This data is directly related to the object of research (Azwar, 2009). For this study, the authors obtained data from a book by Agus Purwanto, a theoretical physicist. Secondary data source is a source that does not directly provide data to data collectors (Sugiyono, 2017). In this case, it can be from the results of previous research, as well as works both published and not.

This study uses data collection techniques with documentation methods, namely by studying various documents related to all the data to be studied (Bungin, 2010). The analytical technique used is the inductive thinking technique, which is a process of organizing a fact or the result of an observation from a separate entity or a generalization (Azwar, 1998). Second, 
deductive thinking technique is the opposite of inductive, which means deducing the relationship from a generalization into separate points (Azwar, 1998).

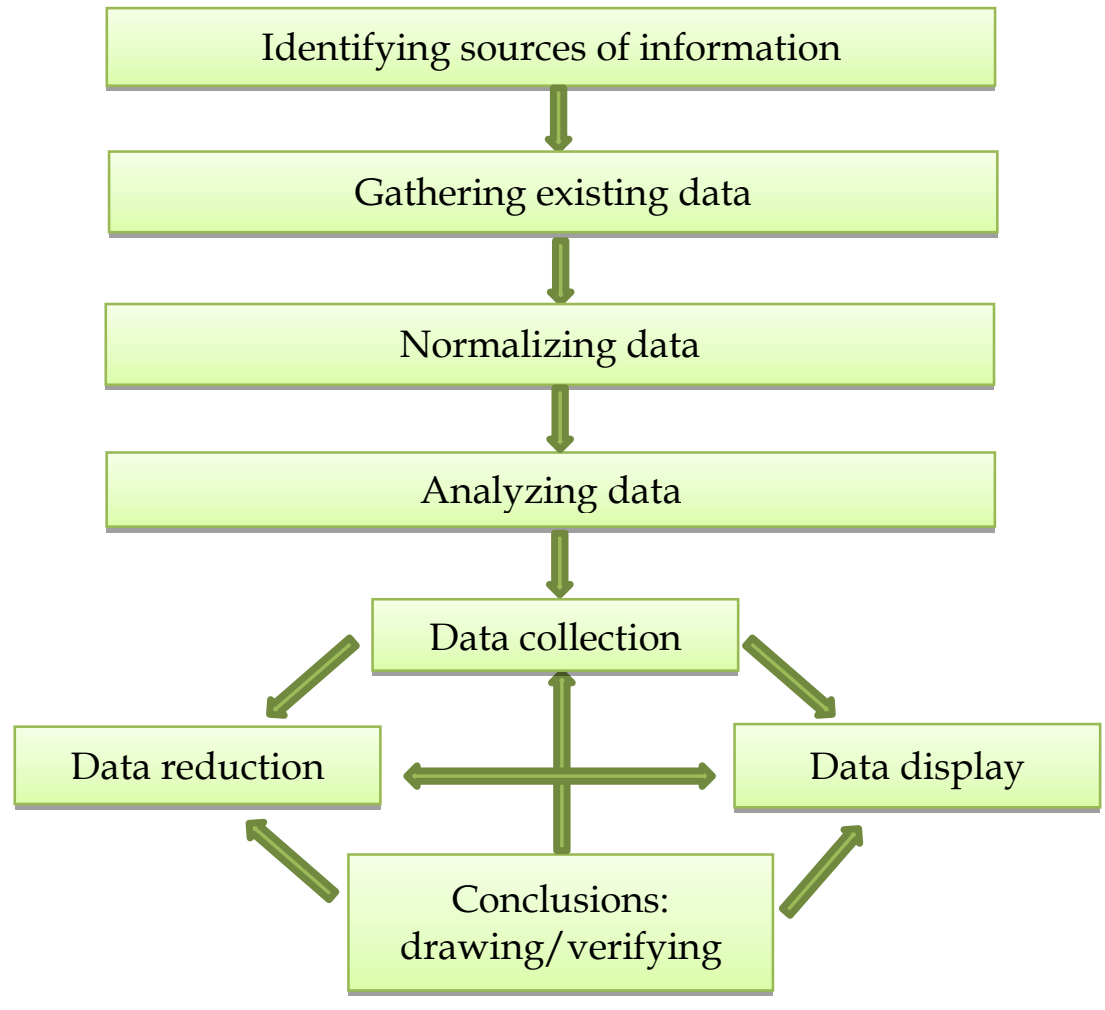

Figure 1. Qualitative research analysis steps

\section{RESULTS AND DISCUSSION}

\section{a. Einstein's Theory of Relativity of Time}

In 1905, Einstein succeeded in presenting his work in his third paper entitled "On the Electrodynamics of Moving Objects". This paper became known as the "Special Theory of Relativity". In this theory, Einstein proposed two postulates, the first postulate or known as the principle of relativity, which states that the laws of physics can be expressed in equations of the same shape in all frames of reference moving at a constant velocity with each other. This postulate states the absence of a universal frame of reference. The second postulate states that the speed of light in a vacuum is the same for all observers, regardless of the state of motion of the observer. From these two postulates it can be concluded that all motion is relative, the speed of light in a vacuum is the same for all observers (Beiser, 1992). As a result of this special theory of relativity, time dilation occurs, or time dilation.

Time dilation is a concept whereby a clock that has a speed will run slower than the clock of a silent person. A silent person and a running person each carry a photon clock or light clock, which is a clock that shows the motion of reflected light in two mirrors. In rest, both lights travel the same distance. But if one of the clocks is moved, the light in the moving photon clock will automatically travel a further distance in the stationary photon clock (Mbagwu, Abu Bakar, \& Ozuomba, 2020). 


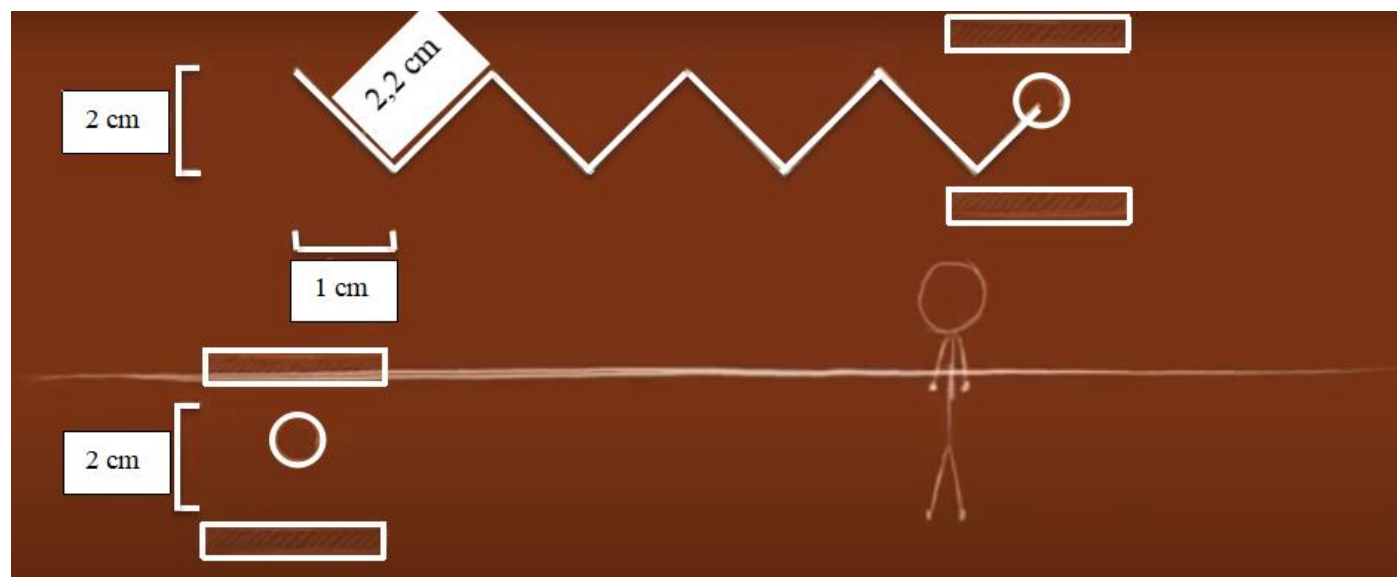

Figure 2. Illustration of relativity of time by a moving and stationary clock

$$
\begin{aligned}
& \left(\frac{c t}{2}\right)^{2}=L_{0}^{2}+\left(\frac{v t}{2}\right)^{2} \\
& \frac{t^{2}}{4}\left(c^{2}-v^{2}\right)=L_{0}^{2} \\
& t^{2}=\frac{4 L_{0}^{2}}{c^{2}-v^{2}}=\frac{\left(2 L_{0}\right)^{2}}{c^{2}\left(1-\frac{v^{2}}{c^{2}}\right)} \\
& t=\frac{2 L_{0} / c}{\sqrt{1-v^{2} / c^{2}}}
\end{aligned}
$$

Since $2 L_{0} / c$ is the time interval $t_{0}$ between the ticks on the bell on earth, as in the previous equation, the equation above becomes

$$
t=\frac{t_{0}}{\sqrt{1-v^{2} / c^{2}}}
$$

A moving bell appears to be ticking slower than a stationary bell, because the light travels in a zig zag path.

Where:

$$
\begin{array}{ll}
t_{0} & =\text { silent time interval of the bell } \\
t & =\text { the time interval of the moving bell } \\
v & =\text { velocity of the object } \\
c & =\text { the speed of light }
\end{array}
$$

Based on the above equation, it is known that the greater the relativistic time will be greater or it is said that the time will expand. If it is analogized, the maximum value will be if it is equivalent to the value (speed of light). This equation also stated that the fastest speed in universe is $c$ (Beiser, 1992).

According to the theory of relativity, if there is an object that has a speed exceeding the speed of light, then time will travel backwards and whatever distance is in front of it will be erased because someone can walk at another time. If a person moves at a speed slower than the speed of light, time will run as usual (Jumini, 2017). 
The theory of relativity is only used in calculations with very high velocities (the speed of light) or high-speed particle problems. Until recently it was developed to reveal the secrets of the microstructure of matter. Therefore, the theory of relativity plays a vital role in revealing events that are difficult to logic. A theory that is actually difficult to digest by the mind will still win the debate, because when the facts say yes, the world will agree with it.

\section{b. The Isra' Mi'raj Event}

Efforts to harmonize science and the Qur'an are increasing day by day. Judging from the development of technology, making all humans compete to explore knowledge to hone their minds. In the theory of relativity, it has been established that the highest speed is the speed of light. However, it turns out that the Qur'an indicates a speed that exceeds the speed of light, namely the Isra' Mi'raj event. The event of the Prophet Muhammad SAW's flight into space by riding a Buraq whose speed was like lightning. Buraq in the literature study defines as a riding animal in the form of a four-legged animal that has high speed. The word Buraq is taken from the word barqu which means lightning. The term is compatible with science, where lightning is defined as light with high speed which is visually incapable of being seen by the eye. Then the Buraq in the Isra' Mi'raj incident will be explained in the quantum physics of annihilation theory. This theory explains a micro particle smaller than an atom, which includes reactions involving the collision of matter and antimatter (Koesminarto, 2007).

The Isra' Mi'raj incident is an extraordinary event because this incident only occurred for about two-thirds of the night with a distance of thousands of kilometers about $1500 \mathrm{~km}$ and a travel time of approximately six hours (Shahab, 2019). Isra' means the journey of Prophet Muhammad SAW at night from the Al-Haram Makkah Mosque to the Al-Aqsa Mosque in Palestine. Mi'raj is the continuation of the Prophet's journey from al-Aqsa Mosque to the sky to Sidratul Muntaha (Purwanto, 2015).

The Isra' incident is described in the Qur'an as follows:

"Glory be to Allah who has run his servants at the night from the Grand Mosque to the Aqsa Mosque that we have blessed around him, for us to show him some of the signs of our (power)." (Surah Al-Isra':1).

Meanwhile, the story of Mi'raj is hinted at by the Qur'an below:

"And actually, Muhammad had seen Jibril (in his original form) at another time, namely at Sidratul Muntaha. Nearby is heaven as a place to live. (Muhammad SAW saw Jibril) when Sidratul Muntaha was overwhelmed by something covering him, Muhammad's vision did not turn away from what he had witnessed and did not (nor did) surpass him. In fact, he has seen some of the signs of the power of his Almighty God." (Surah An-Najm: 13-18).

To facilitate understanding, Einstein's Theory of Relativity of time will first be linked with Surah Al Ma'arij verses 3-4, namely the concept of time dilatation, which concludes that one day of the journey of angels and spirits is equivalent to 50,000 years. "The angels and Jibril rose (facing God in a day, which is equivalent to fifty thousand years" (Surah Al Ma'arij: 4).

By using equation 1 :

$$
\begin{aligned}
& t=\frac{2 L_{o} / c}{\sqrt{1-v^{2} / c^{2}}} \\
& 50.000 \times 365 \text { hari }=\frac{1 \text { hari }}{\sqrt{1-\frac{v^{2}}{\left(3 \times 10^{8} \mathrm{~m} / \mathrm{s}\right)^{2}}}} \\
& v=2.999 .999 .99,999.999 .549 .7084 \mathrm{~m} / \mathrm{s}
\end{aligned}
$$

This explains the speed of the angels approaching the speed of light and this is natural, because angels are created from light (nur). The weakness here is, first, it is not only angels who are created from light but also spirits. So, it is impossible for the Prophet to travel only with his 
soul, because the Prophet could tell in detail what he had experienced. Second, if Mi'raj's journey was carried out at the speed of light 300,000 $\mathrm{km}$ per second, the distance traveled would be 4,320 million $\mathrm{km}$, none other than the Sun-Neptune distance, which means the journey of the new prophet to the planet Neptune. Meanwhile, reaching the nearest star, Alfa Centauri, takes 4.4 years at the speed of light. So, it is impossible for the Prophet to have a dialogue with God there. The third is that if the Prophet Muhammad SAW traveled as fast as light, his body would explode, be massless, and be unlimited in size, this is in accordance with the results of the theory of relativity (Said, 2019).

Thus, Einstein's theory of relativity of time is not sufficient to explain the Isra' Mi' raj event. However, in terms of prerequisites in the theory of relativity of time, the Isra' Mi'raj event can be classified into it. This is because there are differences in the two places that are experienced, namely on earth and in the sky.

Agus Purwanto, tried to explain through the theory of general relativity (curved spacetime), a theory that was also coined by Einstein. Referring to the problem of the expanding universe, where three models are used, namely: the closed, flat, and open universe model. He explained that we live in this world with four dimensions, three dimensions of space and one dimension of time. The results obtained lead to a closed universe. This means that if the Prophet Muhammad SAW carried out the Isra' Mi' raj event, then the journey that was crossed was a ball shape where the Prophet could return without turning his direction. The problem is that it will still take millions of years for the Prophet Muhammad SAW to return to earth (Purwanto, 2015).

It is becoming increasingly clear that the theory of relativity has not been able to prove this extraordinary event. Here it can be said that the Prophet Muhammad SAW came out of our space-time. It should be noted that Einstein's theory of relativity has been able to reveal that time is relative.

In equation 1 , it is revealed that the value of the velocity of an object $(v)$ is equal to the speed of light (c), then the value becomes 1 . Logically if the numerator is very small, then automatically the value of time $(t)$ will be very large or can be said to be infinite. This means that someone will be separated from the dimension of time. Whenever and wherever, someone can go even though they are fond of the past or the future. This term will be known as teleportation. The teleportation experiment was successfully carried out by Charles $\mathrm{H}$. Bennet with a team at the University of Innsbruck Austria with his experiment using a photon. The results showed an exact replica of the original photon (Sadiman \& Karolina, 2017).

Followed by research in 1998 from the California Institute of Technology (Caltech), the same thing involved teleporting a photon sent via a coaxial cable one meter away. Research that has been growing until 2006, research conducted by Dr. Eugene Polzik and formed from the Niels Bohr Institute in Copenhagen by teleporting a beam of laser light in an atomic cloud. Similar results were felt by this study, which is the world's first study by teleporting two different materials (Sadiman \& Karolina, 2017).

The Dirac equation tries to combine the theory of relativity with quantum theory. The equations published in 1928 attempted to reform the Schrodinger equation which was unable to explain the speed of an object, the speed of light, as in an electron. Where the facts show that speed is speed of light. It is clarified in the annihilation theory (the removal process) which states that a matter must have anti-matter. If the second particle is fired, it will vanish and turn into a beam of light known as gamma rays. The statement states that a matter can turn into light. This may be what happened in proving the Isra' Mi'raj incident of Prophet Muhammad SAW.

Do not escape the discussion that has been expressed by physicists. Now the writer tries to see it from the ulama's point of view. Quoted from Habib Anies lecture, he interpreted that the verse begins with a sentence that glorifies Allah, namely "Glory to Allah". This can be believed in the awesomeness of Allah, the Power of Allah. Followed by "who execute His servants". "His" in that sentence refers to Prophet Muhammad SAW. It can be said that Allah is the subject, which means the doer, while the Prophet Muhammad SAW is an object which means 
something that is subject to the work of the subject. From this it is very clear that this event was purely from the will of Allah SWT (Shahab, 2019).

Isra Miraj is not merely a miracle, but Ummul a miracle that is a miracle of reason. A "consciousness-space", an even more subtle magical region whose size is equivalent to a hundred million is even greater. Like the ratio of the foam waves to the contents of the ocean. In this space, the forms and particles of the human body are too coarse. By His own will, the Messenger of Allah underwent a process of transformation, turning into a super-purpose with his super-existence. Muhammad is the only human who has succeeded in reaching the outer limits of this subtle insight and realm, to be precise in Sidratul Muntaha (Misbakhudin, 2012). It does not rule out, that the journey of Isra' Mi'raj is one of the miracles experienced by the Prophet Muhammad SAW. Mu'jizat is an extraordinary event that was carried out by Allah to the Prophet and Rasul to prove His prophethood and apostleship. Based on previous research, it states that the history of Isra' Mi'raj has agreed upon its validity by scholars of hadith and Sirah experts. It has also been established as mentioned in the Al-Qur' an, sahih hadiths, and Ijma' of the Muslims that this event was one of the miracles received by the Prophet Muhammad SAW. Whoever denies it means that he has denied something ma'lûm bid-dharûrah (known with certainty) (Zakaria, 2019). A miracle cannot be proven by any theory, but the main goal as Muslims is to believe in it.

\section{c. The Ashabul Kahf incident}

The youths referred to are the Ashabul Kahf. The young believer who was instructed by Allah SWT to hide in a cave because he was running away from the unbelievers at that time. This young man thought that they only slept for a day or half a day, but the duration they slept for was 309 years. The story is contained in the Qur'an:

"And thus, We awoke them, that they might ask one another. One of them said, "How long have you been (here)?" They replied, "We are (here) a day or half a day." Said (another), "Your God knows better how long you have been (here). So tell one of you to bring your silver coins, and let him see which food is better, and bring some of this food for you, and let him be gentle and never tell anyone about your thing" (Surah Al-Kahf: 19) "and they lived in the cave for three hundred years and plus nine years" (Surah Al-Kahf: 25).

In the above verse it is explained that the Kahf youth slept for 300 years plus 9 years or 309 years. While one of them asked "How long have you slept", another person answered "We only slept for a day or half a day". Many people think that this event has something to do with Einstein's theory of relativity, because it is felt that there is a difference in time experienced by the young Kahf. This effort can be said to be a lack of caution in interpreting the definition of the theory of relativity itself. The occurrence of time polishing is one of the implications of Einstein's theory of relativity of time. Previously, it should be noted that there are factors that are not fulfilled if this phenomenon is related to the theory of relativity of time, namely relative motion. Youths and people at that time both occupied the earth, the difference was that the young man lived in the cave, while other people lived outside the cave. The youth in the cave did not move relative to the person outside the cave. Because of this, the theory of relativity of time will not give a time difference between the two. This means that the three hundred and nine years experienced by the young man will be the same as three hundred and nine years for other people (outside the cave). Thus, time dilation or time polishing does not apply in this case (Purwanto, 2015).

If seen from the verse that follows "And we covered their ears for several years in the cave" there will be a connection with both physical and biological aspects. However, the author will not discuss this aspect further.

The time the youth perceives as a day or half a day has a message that may need to be pondered. During the sleep story of the young Kahf, it may be related to the calendar system itself. Muslims recognize two kinds of calendar systems, namely the Syamsiyah calendar and the Qamariyah calendar. In the above verse Allah implies that the Kahf youth slept in the cave 
for 300 years of Syamsiyah or 309 years of Qamariyah. One Syamsiyah year has 365 days or more precisely 365.1422 days. The Qamariyah year has 354 days or more precisely 354.363760 days. The amazing thing is obtained from the difference in the number of days between the Syamsiyah year and the Qamariyah year which is 365 days-354 days $=11$ days. Thus, the time difference between 33 Syamsiyah years and Qamariyah years is 368 days or the equivalent of 1 Qamariyah year. So, in every 100 Syamsiyah years, the Qamariyah year number will be 3 years more. Thus, 300 years of Syamsiyah will be equal to 309 years (Thayyarah, 2014).

Where Muslims use a time system that uses the lunar system, or the Qamariyah calendar. In the Syamsiyah calendar system in one year it consists of 365.1422 days, while in the Qamariyah calendar system it consists of 354.363760 days. The ratio of the number of days in a year for these two calendar systems is $354.363760 / 365.1422=0.97049$. Which this number is almost the same as the time stated in the Ashabul Kahf event, 300/309 $=0.97087$ (Purwanto, 2015). That is, the number of days in the Christian calendar system and the Qamariah calendar have approached the truth. With this it can be said that the difference in time felt by the Kahf youth was not a time dilation, but an implicit time calculation.

\section{CONCLUSION}

Einstein's theory of relativity has no connection with the Ashabul Kahf incident, due to unfulfilled factors. The difference in time felt by Kahf youth led to the Muslim calendar system, namely the Qamariyah and Syamsiyah calendars. The theory of relativity is able to clearly prove how the difference between the time of day experienced by angels and the clock on earth for fifty thousand years. Meanwhile, in the Isra' Mi'raj Prophet Muhammad SAW event, Einstein's theory of relativity of time was related to this event. Due to the discussion which has not been able to prove concretely or theoretically, this event has not yet been revealed if reasoned with logic. However, it needs to be realized that the Isra' Mi'raj incident was a miracle of Allah to the Prophet Muhammad SAW. So, it is possible that this incident is purely God's will. The existence of Einstein's theory of relativity, gradually leads someone that it is true that the main source of knowledge is in the Al Qur'an. Scientific scholarship is proof of the truth of the Qur'an. Moreover, Al Qur'an is the word of Allah sent down through the angel Gabriel. Allah has the power to abolish or abolish space and time because with only one kun word (be) (Thayyarah, 2014).

This study is inseparable from the many limitations that are known through analysis along the way. The weaknesses felt by researchers need to be expressed in order to realize perfection for further research with the same theme. Among them: there is no direct data collection (interviews) through physicists and interpreters of the Qur'an, and a lack of references from relevant tafsir books. Because there is still limitation in this study, to overcome it is due future research by conducting in-depth interviews with sources, and also conducting developing research that includes aspects from other branches of science related to the topic of this research.

\section{ACKNOWLEDGEMENTS}

Thank you to all reviewers who with all the time and expertise to review and evaluate as well as help us in finalization of this scientific article.

\section{REFERENCES}

Ain, Nurul, T., \& Ashari, F. (2018). Isra' Mi'raj dalam kajian Al Quran dan Sains. Jurnal Inovasi Pendidikan Fisika dan Integrasinya, 1 (2), 29-34.

Azwar, S. (1998). Metode penelitian. Pustaka Belajar.

Azwar, S. (2009). Metode penelitian. Pustaka Belajar.

Beiser, A. (1992). Konsep fisika modern (4 ed.). (T. H. Liong, Trad.). Erlangga.

Bungin, H. M. (2010). Penelitian kualitatif. Kencana Prenada Media Grup. 
Faizin, F. (2020). Kisah Al Quran dalam tinjauan sains: Studi atas serial tafsir ilmi Kementrian Agama RI. Jurnal Studi Al Quran dan Hadits, 4(1), 77-96.

Harahap, N. (2014). Penelitian kepustakaan. Jurnal Iqra, 8(4), 68-73.

Istiqimah, H., \& Sholeh, M. I. (2020). The concept of Buraq in the events of Isra' Mi'raj: Literature and physics perspective. Academic Journal of Islamic Studies, 5(1), 53-68.

Jumini, S. (2017). Relativitas Einstein terhadap waktu ditinjau dari Al Quran surat Al Ma'arij ayat 4. Jurnal Studi Al Quran dan Hukum, 3(2), 159-172.

Koesminarto. (2007). Fisika dan Penerapannya dalam Bidang Medis. UGM Press.

Lailiyah, S. (2020). Keilmiahan sains adalah bukti kebenaran Al Quran. Prosiding Seminar Nasional Pendidikan Fisika, 2(1), 204-216.

Margono, S. (2009). Metodologi penelitian pendidikan. Rineka Cipta.

Mbagwu, J. C., Abu Bakar, Z. L., \& Ozuomba, Z. O. (2020). A review article on Einstein special theory relativity. International Journal of Theoretical and Mathematical Physics, 10(3), 65-71.

Misbakhudin. (2012). Isra' Mi'raj sebagai mukjizat akal. Jurnal Religia, 15(1), 14-26.

Purwanto, A. (2015). Ayat-Ayat Semesta: Sisi-sisi Al Quran yang terlupakan. Mizan.

Rahmati. (2017). The journey of Isra' and Mi'raj in Qur'an and science perspective. International Journal of Islamic Studies, 4(2), 323-336.

Sadiman, \& Karolina, A. (2017). Pendekatan saintifik kuantum dalam memahami perjalanan Isra' Nabi Muhammad SAW: Teori saintifik modulasi quantum Isra'. Jurnal Kajian Keislaman dan Kemasyarakatan, 2(2), 200-225.

Said, H. (2019). Metode Tafsir Ayat-Ayat Kauniyah: Studi Atas Tafsir Ayat-Ayat Semesta Sisi-Sisi AlQur'an Yang Terlupakan Karya Agus Purwanto [Undergraduate honors thesis, The State Islamic Institute of Surakarta]. https://core.ac.uk/download/pdf/296480142.pdf

Shahab, M. A. (2019). Sejengkal lebih dekat dengan Sang Pemberi Syafaat. Ma'had Alhijrah Annabawiyah.

Sugiyono. (2017). Metode penelitian kualitatif kuantitatif dan RED. Alfabeta.

Thayyarah, N. (2014). Buku pintar sains dalam Al Quran. Dar Al-Yamama, Abu Dhabi.

Wardah, L. (2018). Konsep waktu dalam Al Quran (Studi tafsir tematik) (Publication No. 5136) [Undergraduate honors thesis, The State Islamic Institute of Ponorogo]. Electronic Theses IAIN Ponorogo. http://etheses.iainponorogo.ac.id/id/eprint/5136

Zakaria, A. (2019). Isra Mi'raj sebagai perjalanan religi: Studi analisis peristiwa Isra Mi'raj Nabi Muhammad menurut Al Quran dan Hadits. Jurnal Ilmu Al Quran dan Tafsir, 4(1), 99-112.

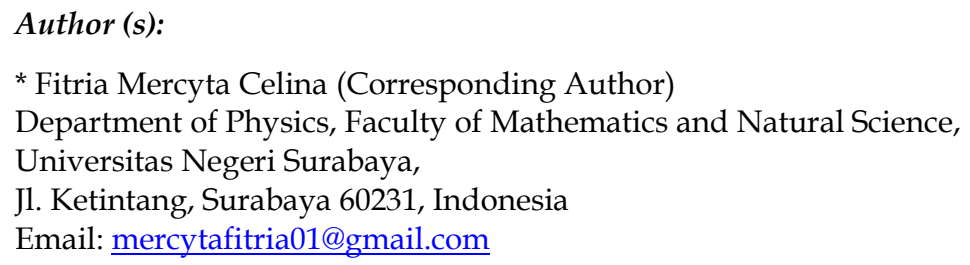

